\title{
The development of drug resistance mutations K103N Y181C and G190A in long term Nevirapine-containing antiviral therapy
}

Yuncong Wang ${ }^{1,2}$, Hui Xing ${ }^{2 *}$, Lingjie Liao ${ }^{2}$, Zhe Wang ${ }^{3}$, Bin Su ${ }^{4}$, Quanbi Zhao ${ }^{2}$, Yi Feng ${ }^{2}$, Pengfei Ma ${ }^{2}$, Jia Liü ${ }^{3}$, Jianjun $\mathrm{Wu}^{4}$, Yuhua Ruan ${ }^{2}$ and Yiming Shao ${ }^{2}$

\begin{abstract}
Objective: We built a cohort study of HIV patients taking long-term first-line Antiretroviral Therapy in 2003. In this assay, we focused on the development of primary drug resistance mutations against Non-Nucleoside Reverse Transcriptase Inhibitor (NNRTI), K103N, Y181C and G190A.

Method: The cohort study was built in Henan province, China. We used Single Genome Amplification (SGA) to analyze the frequency of K103N, Y181C and G190A in serial plasma samples of three individual patients. We also performed standard genotype HIV drug resistance assay in 204 patients of this cohort study to analyze the frequency of these mutations.

Result: In the SGA sequences, the K103N decreased and vanished, while the frequency of Y181C and G190A increased in individual patient receiving long-term Antiretroviral Therapy (ART). In the sequences of standard genotype HIV drug resistance assay, the frequency of K103N, Y181C and G190A had the similar pattern with that in SGA sequences. Among these patients, the viral suppression were still sufficient after receiving ART for 72 months, and $78.6 \%$ (160/204) patients could have their CD4 count over than 200cells/ul.

Conclusion: In some patients, first-line ART had the possibility to provide sufficient treatment effect for over than 72 months, but in long-term treatment, the dominant NNRTI drug resistance mutation K103N could reduced, while the proportion of variants with mutation Y181C or G190A may increased. This result was not similar with that in vitro study, which state that variant with K103N or Y181C had an equal viral fitness with wild type.
\end{abstract}

Keywords: K103N, Y181C, G190A Navirapine (NVP), Antiviral therapy, Cohort study

\section{Background}

Antiretroviral therapy (ART) in China started in 2003 [1], at the end of 2011, over 350,000 HIV-infected patients were receiving ART [2]. Chinese national treatment guidelines for ART is: (1) CD4 cell count, $350 / \mathrm{mm}^{3}$ (increased from $200 / \mathrm{mm}^{3}$ in 2008); (2) total lymphocyte count, $1,200 / \mathrm{mm}^{3}$; or (3) World Health Organization (WHO) stage III or IV disease [3]. The first-line regimen included two kinds of Nucleoside Reverse Transcriptase Inhibitors (NRTI) and one kind of Non-Nucleoside

\footnotetext{
*Correspondence: xingh@chinaaids.cn

${ }^{2}$ State Key Laboratory for Infectious Disease Prevention and Control, National Center for AIDS/STD Control and Prevention, Chinese Center for Disease Control and Prevention, Collaborative Innovation Center for Diagnosis and Treatment of Infectious Diseases, Beijing, China

Full list of author information is available at the end of the article
}

Reverse Transcriptase Inhibitor (NNRTI) [4]. Because of very limited antiretroviral drug formulations and lack of adequate laboratory monitoring of ART patients, most patients who initiated ART during the early phase of the free ART program had to stay on the same regimen for a long period of time (maximum for 112 months in my research). For this fact, the research on the development of drug resistance mutations in long-term ART became more and more necessary.

NNRTIs is a crucial component of Chinese ART, it exhibit a longer plasma half-life and a longer duration of detectable levels than nucleoside analog reverse transcriptase inhibitors (NRTIs) [5]. Nevirapine (NVP) is an acceptable first-line NNRTI for HIV-1-infected patients [6] and is known as the most common NNRTI used in 
the ART regimens of China. In our research, all patients took NVP as NNRTI in their regimens, and were never been stopped and changed.

NVP is a potent NNRTI to fight against HIV, but it has two drawbacks: one, it could cause allergic reactions in approximately $5-14 \%$ of users worldwide [7-9], another one is that NVP has a low genetic barrier; a single mutation can lead to a high-level drug resistance against NVP $[10,11]$. Among the NNRTI drug mutation, K103N, Y181C and G190A are the most common mutation associated with resistance to NVP [12,13]. Even in the patients before ART, Low frequencies of K103N and Y181C are significantly associated with an increased risk of virologic failure [14]. In vitro study, K103N, Y181C and G190A could not provide significant fitness reduction to HIV viruses, variant with these mutations had similar viral replication fitness with the wild type variant $[15,16]$. In the past, consider the low fitness reduction and high-level resistance of NNRTI associated mutations, researchers seldom paid attention to the NNRTIs resistant profiles resulting from therapy failure, because a single NNRTI treatment failure always means the second NNRTI therapy failure $[17,18]$, and in countries with rich ART resources, patients with NNRTI drug resistance mutations would switch to new regimen but in China, a country with limited antiretroviral drugs, patients had to took same NNRTI drug for long time, so the understanding of the development of NNRTI associated mutations became very necessary.

In this essay, we retrospectively studied the development of K103N, Y181C and G190A in long-term ART.

\section{Method}

\section{Study population}

National Center for AIDS/STD Control and Prevention built an observational cohort study enrolled 339 patients from Queshan County, Henan Province from December 2003 to December 2004. Patients who were 18 years of age or older and started ART between 2003 and 2004 were included. All patients agreed to participate in the study through informed consent. Patients were followed every 6 months up to 11 November 2012. Due to stopping ART, death or losing to follow-up. By the end of 2012, among these 339 patients, 75 patients died for AIDS associated diseases, 34 patients stopped ART, and 26 patients lost to follow-up, so we had 204 patients for this study.

204 patients in this cohort study were all treated with AZT/ddI/NVP (AZT, $300 \mathrm{mg} 2$ times/day; ddI, $200 \mathrm{mg}$ 2 times/day; NVP, $200 \mathrm{mg}$, 2 times/day). Treatment adherence was assessed by questionnaire in each follow-up. The number of patients who had over 95\% adherence in each follow-up showed no significant difference ( $p>0.05)$.

Sample collection was approved and done by Henan CDC. In each follow-up, Neibor Joining phylogenetic analysis was performed to confirm that the longitudinal samples were from the same patient, and all the information of patients and the results of drug resistance assays were all well stored by China CDC. All patients took Nevirapine (NVP) as the NNRTI in regimen from the initial time and have never been changed (Table 1).

To assess the ART outcome, the date of virologic failure was defined as the first recorded date of plasma viral load of more than 5000 copies $/ \mathrm{ml}$ after 6 months of treatment, as the 2010 WHO guideline on antiretroviral therapy for HIV infection in adults and adolescents (WHO. Antiretroviral therapy for HIV infection in adults and adolescents: recommendations for a public health approach. 2010). Similarly, the date of immunologic failure was also defined by WHO criteria as the earliest date of any one of the following after 6 months of treatment: posttreatment CD4+ cell count falling to or below baseline $\mathrm{CD} 4^{+}$cell count; $50 \%$ decrease from peak $\mathrm{CD}^{+}$cell count; or two consecutive $\mathrm{CD}^{+}$cell counts of less than 100 cells $/ \mathrm{ml}$ or last $\mathrm{CD} 4^{+}$cell count of less than 100 cells $/ \mathrm{ml}$. Baseline CD4 $4^{+}$ cell count was defined as the last pretreatment count within 6 months of treatment. If no pretreatment $\mathrm{CD} 4^{+}$ cell count was done, the earliest count within 1 month of starting treatment was used for the baseline value.

\section{Table 1 Characteristics of HIV-infected study population on antiretroviral cohort study Henan Province, central} China

\begin{tabular}{ll}
\hline Characteristics & N (\%) N = 3399 \\
\hline Sex & $143(42.2)$ \\
Male & $194(57.8)$ \\
Female & $39(25-64)$ \\
Median age at inclusion & \\
Education & $218(64.2)$ \\
$\quad$ Primary school or less & $119(35.8)$ \\
$\quad$ Middle school or more & \\
Marital status & $287(84.6)$ \\
$\quad$ Married or living with partner & $52(15.4)$ \\
$\quad$ Single, divorced or widowed & \\
Occupation & $327(96.5)$ \\
Farmer & $12(3.5)$ \\
Other & \\
Risk exposure & $327(96.5)$ \\
Former plasma donor & $7(2.1)$ \\
Sexual transmitted & $5(1.4)$ \\
Unknown &
\end{tabular}


In this study, we used plasma specimens of four time points: treatment for 6-18 months; 30-42 months; 54-67 months and 75-102 months. Among the 204 patients, we select 3 patients for Single Genome Amplification (SGA). The criteria was (1) at least 6 time points; (2) no stopping and restarting ART, (3) the results of CD4 count and viral load were all available.

\section{Laboratory methods}

Standard genotype HIV drug resistance assay was performed on the specimens in the four time points mentioned above. SGA were performed in 3 patients. They were all performed in the National center for HIV/STD diseases control and prevention, China CDC. In each follow-up, viral load assays were performed by M2000 Biosystem (Abbott Company, USA). The CD4 cell count for all patients were performed by FACSalibur flow cytometer (BD Company, USA).

\section{Viral RNA extraction and standard genotyping}

Viral RNA were extracted from plasma samples using QIAamp Viral RNA Mini Kit (QIAGEN company). We used nested RT-PCR process to get a $1.3 \mathrm{~kb}$ (2253-3553) fragment of pol gene, the fragment includes Protease amino acid codons 1-99 and Reverse transcriptase amino acid codons $1-300$. The sequences of primers for the first round RT-PCR process could be seen below: MAW265'-TTGG AAATGTGGAAAGGAAGGAC-3 and RT215'-CTGTAT TTCTGCTATTAAGTCTTTTGATGGG-3'. PCR temperature was $50^{\circ} \mathrm{C}, 30 \mathrm{~min}$ for reverse transcription, $94^{\circ} \mathrm{C}$, $10 \mathrm{~min}$ for preheat, followed by $94^{\circ} \mathrm{C}, 30 \mathrm{~s} ; 55^{\circ} \mathrm{C}, 30 \mathrm{~s} ; 72^{\circ} \mathrm{C}$, $2 \mathrm{~min} 30 \mathrm{~s}, 30$ cycles. $72^{\circ} \mathrm{C} 10 \mathrm{~min}$ for final amplification. In the second round, we got a $1.3 \mathrm{~kb}$ fragment using primer RT205'-CTGCCAGTTCTAGCTCTGCTTC-3' and PRO15'-CAGAGCCAACAGCCCCACCA-3'. PCR temperature was $94^{\circ} \mathrm{C}, 10 \mathrm{~min}$ for preheat, followed by $94^{\circ} \mathrm{C}, 30 \mathrm{~s} ; 55^{\circ} \mathrm{C}, 30 \mathrm{~s} ; 72^{\circ} \mathrm{C}, 2 \mathrm{~min} 30 \mathrm{~s}, 30$ cycles. $72^{\circ} \mathrm{C}$ $10 \mathrm{~min}$ for final amplification.

\section{Single genome amplification (SGA)}

RNA was extracted from plasma specimens by QIAamp Viral RNA Mini kit (Qiagen, Germany), and was reverse transcript to cDNA by SuperScriptIII protocol according to the manufacturer's instructions (Invitrogen LifeTechnologies, USA). We then dilute cDNA to a moderate concentration in 96-well plates, such that fewer than 29 PCRs yielded an amplification product. According to probability theory, once less than 30\% PCR reactions get positive results in 96-well plates, it has more than $80 \%$ to get each sequence amplified from a single genome $[19,20]$.

We used 3730 Sequencer (ABI company, USA) to get sequences from all the positive amplification products, and use Sequencher (4.10.1) to clean and edit sequence data. In an individual sequence, if there is no ambiguous base pair, it was confirmed that this sequence amplified from a single genome. Finally, we got about 20 such single genome sequences for each time point.

\section{Data analysis (Ka/Ks Ratio of NNRTI associated mutations)}

$\mathrm{Ka} / \mathrm{Ks}$ ratio is a tool to characterize selection pressure of observed amino acid mutations over observed synonymous mutations, the ratio of the number of nonsynonymous substitutions per non-synonymous site (Ka) to the number of synonymous substitutions per synonymous site (Ks) [21]. Ka/Ks ratio was used as an indicator of selective pressure acting on a protein-coding gene. A $\mathrm{Ka} / \mathrm{Ks}$ value of 1 indicates neutral selection, which means amino acid changes are neither being selected for nor against. A Ka/Ks value of $<1$ means negative selection pressure. That is, most amino acid changes are baneful and are selected against. The positive selection $(\mathrm{Ka} / \mathrm{Ks}>1)$ is much rare, indicating that amino acid changes are favored and may be useful [22].

The concept of correlated mutations is one of the basic ideas in evolutionary biology. The amino acid substitution rates are expected to be limited by functional constraints. Given the functional constraints operating on gene, a mutation in one position can be compensated by an additional mutation. Then mutation patterns can be formed by correlated mutations responsible for specific conditions. Here, we used conditional $\mathrm{Ka} / \mathrm{Ks}$ ratio $(\mathrm{cKa} / \mathrm{Ks})$, which is a metric to measure the effects of mutations at one site on the selection pressure for mutations at another site.

We conducted $\mathrm{cKa} / \mathrm{Ks}$ ratio analysis on two dataset, one is RT gene sequences of 204 patients using standard HIV genotype sequencing, the other one is RT gene sequences of three patients using Single Genome Amplification. In the two dataset, we had two time points, one was receiving ART for 12 months (10-14 months), and the other time point was receiving ART for over 60 months (56-73 months).

In dataset one, because it is nearly impossible to get gene sequence from plasma samples with suppressed viral load, there were 75 sequences for the first time point, and 74 for the second time point, in dataset two, we had 99 sequences for the first time point and 109 for the second time point. All the $\mathrm{cKa} / \mathrm{Ks}$ analysis was done by $\mathrm{R}$ Language, using the package CorMut (1.2.0, Zhenpeng Li ).

\section{Ethics approval}

Chinese Center for Disease Control and Prevention research ethics boards approved this study.

\section{Result}

\section{General information}

Because of transferring to another clinic center, immigrating to other town, not all the 204 patients participated in four follow-ups of this cohort study. There were 184, 148, 
200 and 182 patients participated in each follow-up respectively.

The median treatment duration $[\mathrm{M}(\mathrm{P} 25 \sim \mathrm{P} 75)]$ of the 204 patients was 86.4 months (77.6-98.0 mo). There were 46 patients receiving ART for over 100 months (22.5\%). Among the 204 patients, the main age range was 30-45 years $(56.4 \%)$, maximum for 63 , minimum for 24 . Male female ratio was $0.6: 1$.

\section{The frequency of K103N, Y181C and G190A in SGA}

The frequencies of three primary NNRTI drug resistance mutations, K103N, Y181C and G190A, fluctuated during long-term ART. More specifically, K103N decreased, while Y181C and G190A showed increasing trend (Table 2).

In the patient HENDRC593, the frequency of K103N showed a decreasing trend, especially from 44.8 months, the K103N vanished in SGA sequences. On the contrary, G190A showed a dramatic increasing trend from the initiation of ART.

In patients ANHDRC106, after taking ART for 23.9 months, K103N and Y181C became dominant mutations $(100 \%)$, while the frequency of G190A was $10 \%$. In the follow-up time points, K103N showed a decreasing trend and G190A showed an increasing trend, while Y181C maintained dominant.

In patients HENDRC622, K103N showed a decreasing trend from 20.5 to 61.5 months, while G190A kept 100\% in quasispecies. The Y181C increased slightly from $0.0 \%$ to 31.6\% from receiving ART for 44.7 months to 61.5 months

The research of Jiong Wang [23] stated that mutation K101E + G190S replicate better with NNRTI drug. Here we showed the frequency of K101E in each time points. It is interesting that the frequency of K101E changed with G190A. In patient HENDRC593, the frequency of K101E increased from $64.7 \%$ to $100 \%$ in 49.9 months, while the frequency of G190A increased exactly from $64.7 \%$ to $100 \%$ in 49.9 months. In patient ANHDRC106, the frequency of K101E increased from $0 \%$ to $100 \%$ in 46.4 months, while the frequency of G190A increased from $10 \%$ to maximum $84.6 \%$ in 46.4 months. In patients HENDRC622, the frequency of G190A kept in 100\% in nearly all time points, while the frequency of K101E kept under $30 \%$.

\section{Standard genotyping: the frequency of K103N, Y181C and G190A in long-term cohort study}

All drug resistance assays were done by 20 December 2012. All the 204 patients took NVP from the initiation of ART treatment and never changed to another NNRTI drug. We collected the treatment and drug resistance results in 4 time points of the 204 patients: 1.ART for 6-18 months; 2 . ART for 30-42 months; 3 . ART for $54-$ 67 months; 4. ART for 72-102 months. Then we calculated and analyzed the frequency of K103N, Y181C and

Table 2 NNRTI mutations and treatment information for three individual patients in SGA

\begin{tabular}{|c|c|c|c|c|c|c|c|c|}
\hline ART duration & Patient ID & Viral load & CD4 count & K103N & G190A & Y181C & K101E & SGA quantity \\
\hline 20.5 & HENDRC593 & 500 & 498 & $6(35.3)$ & $11(64.7)$ & $6(35.3)$ & $11(64.7)$ & 17 \\
\hline 27.5 & & 500 & 691 & $8(42.1)$ & $11(57.9)$ & $8(42.1)$ & $11(57.9)$ & 19 \\
\hline 38.9 & & 2976 & 770 & $4(26.7)$ & $11(73.3)$ & $7(46.7)$ & $11(73.3)$ & 15 \\
\hline 44.8 & & 91000 & 655 & $3(15.8)$ & $16(84.2)$ & $5(26.3)$ & $16(84.2)$ & 19 \\
\hline 49.9 & & 120000 & 595 & $0(0.0)$ & $23(100.0)$ & $2(8.7)$ & $23(100.0)$ & 23 \\
\hline 61.5 & & 52000 & 696 & $0(0.0)$ & $16(94.1)$ & $5(29.4)$ & $16(94.1)$ & 17 \\
\hline 76.1 & & 170000 & 551 & $0(0.0)$ & $20(100.0)$ & $9(45.0)$ & $18(90.0)$ & 20 \\
\hline 23.9 & ANHDRC0106 & 44730 & 222 & $10(100.0)$ & $1(10.0)$ & $10(100.0)$ & $0(0.0)$ & 10 \\
\hline 30.1 & & 159000 & 196 & $5(41.7)$ & $3(25.0)$ & $12(100.0)$ & $7(58.3)$ & 12 \\
\hline 35.5 & & 94700 & 255 & $5(33.3)$ & $3(20.0)$ & $15(100.0)$ & $10(66.7)$ & 15 \\
\hline 42.6 & & 379000 & 153 & $3(21.4)$ & $3(21.4)$ & $14(100.0)$ & 11 (78.6) & 14 \\
\hline 46.4 & & 17600 & 294 & $0(0.0)$ & $11(84.6)$ & $13(100.0)$ & $13(100.0)$ & 13 \\
\hline 52.6 & & 33100 & 256 & $1(7.1)$ & $10(71.4)$ & $14(100.0)$ & $13(92.9)$ & 14 \\
\hline 20.5 & HENDRC622 & 2076000 & 104 & $10(83.3)$ & $10(83.3)$ & $0(0.0)$ & $2(16.7)$ & 12 \\
\hline 27.4 & & 7263 & 164 & $14(93.3)$ & 15 (100.0) & $0(0.0)$ & $1(6.7)$ & 15 \\
\hline 33.0 & & 17160 & 142 & $12(75.0)$ & $16(100.0)$ & $0(0.0)$ & $4(25.0)$ & 16 \\
\hline 44.7 & & 13160 & 138 & $9(81.8)$ & $11(100.0)$ & $0(0.0)$ & $2(18.2)$ & 11 \\
\hline 49.9 & & 66000 & 176 & $9(90.0)$ & $10(100.0)$ & $1(10.0)$ & $1(10.0)$ & 10 \\
\hline 56.8 & & 81000 & 130 & $4(22.2)$ & $18(100.0)$ & $2(11.1)$ & $5(27.8)$ & 18 \\
\hline 61.5 & & 39000 & 181 & $8(42.1)$ & 19 (100.0) & $6(31.6)$ & $1(5.3)$ & 19 \\
\hline
\end{tabular}


G190A in the four time points (Figure 1). Frequency of K103N showed a decreasing trend while both the frequency of Y181C and G190A showed an increasing trend. Specifically, the frequency of K103N had a negative correlation with treatment duration, and mutation G190A had positive correlation with treatment duration. The frequency of mutation Y181C and treatment duration did not show significant correlation.

We also analyzed the frequency of K101E in 204 patients, but here we showed the correlated rate of K101E and G190A in four time points, they were 3/9, 4/16, 7/23, 10/27 (about 30\%).

Treatment effect in long-term Nevirapine-contain ART

At the time point of receiving ART for 6-18 months, $84.8 \%$ patients had their CD4 cells counts over 200 cells/ $\mathrm{ml}$. At the time point of receiving ART for over 72 months, there were still $78.6 \%(143 / 182)$ patients had their CD4 counts over 200 cells $/ \mathrm{ml}$.

For viral load, there were $39.1 \%$ patients failed to suppress their viral load in initial period (6-18 months). After receiving ART for over 72 months, $44.5 \%$ patients failed to suppress their viral load; it indicated that the first-line ART had the possibility to provide treatment effect in $55.5 \%$ patients (Table 3 ).

Besides the 204 patients, we had three patients performed SGA experiments, all of them had received ART for over 50 months, the maximum one is 76.1 months. After long-term ART, the viral load were failed to be suppressed sufficiently, but the CD4 count were kept steady and were similar with the initial time of ART. The longterm ART appeared to postpone the development of HIV virus.

The correlated mutations with K103N, Y181C and G190A (result of $\mathrm{cKa} / \mathrm{Ks}$ ratio)

In the result of $\mathrm{cKa} / \mathrm{Ks}$ analysis all positively correlated mutations $(\mathrm{cKa} / \mathrm{Ks}>1)$ were listed here in Tables 4 and 5 , mutations with $\mathrm{cKa} / \mathrm{Ks}$ smaller than 1 were not included in the tables. Mutations in Position 1 were the condition mutations, mutations in Position 2 were the accessory mutations that were favored by ART with mutations in Position 1. It showed that M41L, D67N, T69D, K70R, and K219R were the most common NRTI mutations that

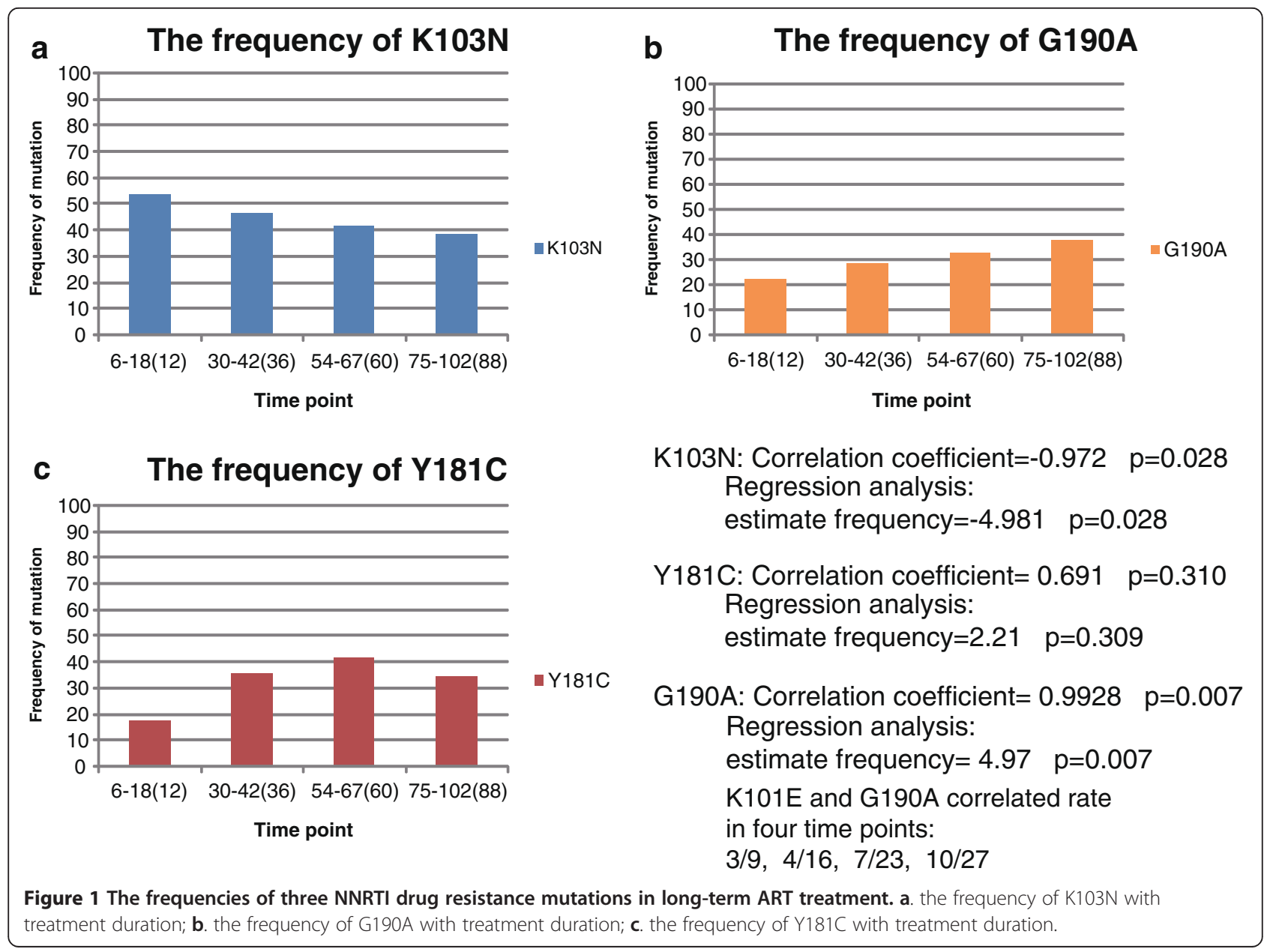


Table 3 Treatment effect of long-term ART in 204 patients

\begin{tabular}{|c|c|c|c|c|c|}
\hline Treatment duration(months) & $\begin{array}{l}\text { Number of } \\
\text { patients }\end{array}$ & $\begin{array}{c}\text { Patients with } \\
\text { CD4 > } 200 \text { cells/ } \mu \mathrm{l}\end{array}$ & $\begin{array}{l}\text { Patients with } \\
\text { VL > LDL }\end{array}$ & $\begin{array}{l}\text { Patients with NNRTIdr and } \\
\text { CD4 > } 200 \text { cells } / \mu \mathrm{l}\end{array}$ & $\begin{array}{c}\text { Patients with } \\
\text { NNRTIdr } \\
\end{array}$ \\
\hline $6-18$ & 184 & $156(84.8 \%)$ & $72(39.1 \%)$ & $34(77.3 \%)$ & 44 \\
\hline $30-42$ & 148 & $114(77.0 \%)$ & $95(64.2 \%)$ & $43(76.8 \%)$ & 56 \\
\hline $54-67$ & 200 & $147(73.5 \%)$ & $105(52.5 \%)$ & 49 (70.0\%) & 70 \\
\hline 72-102 & 182 & 143 (78.6\%) & 81 (44.5\%) & $56(77.8 \%)$ & 72 \\
\hline
\end{tabular}

notes:1. The number in this table refer to the number of certain patients, while proportions are in brackets.

2. VL refer to viral load,LDL refer to the lowest detectable viral load of certain method.

associated with the three NNRTI mutations, K103N, Y181C and G190A. In NNRTI mutations besides K103N, Y181C and G190A themselves, H221Y was the most common NNRTI mutations associated with the three NNRTI mutations.

Among K103N, Y181C and G190A, some correlations could be found, but they were not always positively correlated, the correlated mutations network changed with the time of ART. For example, in standard genotype sequencing dataset when receiving ART for 12 months Y181C, G190A and H221Y were positively correlated with K103N, but when receiving ART for over 60 months,

Table 4 Correlated mutations in standard genotype sequencing dataset

\begin{tabular}{|c|c|c|c|c|c|}
\hline & Position 1 & $\begin{array}{c}\text { Mutation } \\
\text { type }\end{array}$ & Position2 & Ckaks & Lod \\
\hline \multirow[t]{8}{*}{ ART for 12 months } & K103N & NRTI & M41L & 1.5 & 7.05 \\
\hline & & NNRTI & Y181C & 1.29 & 5.17 \\
\hline & & & G190A & 1.6 & 5.22 \\
\hline & & & H221Y & 5 & 2.87 \\
\hline & Y181C & NRTI & None & None & None \\
\hline & & NNRTI & H221Y & 6 & 3.45 \\
\hline & G190A & NRTI & None & None & None \\
\hline & & NNRTI & K103S & 3 & $\operatorname{lnf}$ \\
\hline \multirow{15}{*}{$\begin{array}{l}\text { ART for over } \\
60 \text { months }\end{array}$} & K103N & NRTI & T69N & 1.33 & 2.39 \\
\hline & & & K70R & 1.17 & 3.32 \\
\hline & & NNRTI & Y181C & 1.27 & 7.16 \\
\hline & & & H221Y & 2.75 & 5.5 \\
\hline & Y181C & NRTI & $\mathrm{D} 67 \mathrm{~N}$ & 1.8 & 3.77 \\
\hline & & & $\mathrm{T} 69 \mathrm{~N}$ & 2.5 & 5.85 \\
\hline & & & K70R & 5 & 4.95 \\
\hline & & NNRTI & $\mathrm{K} 103 \mathrm{~N}$ & 2 & 15.78 \\
\hline & & & H221Y & 4 & 6.05 \\
\hline & G190A & NRTI & D67N & 4.8 & 3.52 \\
\hline & & & T69N & 4 & 5.71 \\
\hline & & & K70R & 3 & 3.52 \\
\hline & & NNRTI & K101E & 6 & 3.52 \\
\hline & & & Y181C & 1.5 & 4.11 \\
\hline & & & K103S & 10 & $\operatorname{lnf}$ \\
\hline
\end{tabular}

Y181C and H221Y were positively correlated with K103N, while G190A was not.

Besides the mutations conferring drug resistance effect, there were a number of accessory mutations or compensatory mutations that correlated with the three NNRTI mutations, more specifically, 5 mutations for G190A in 12 months 14 ones for $\mathrm{K} 103 \mathrm{~N}$, and 9 for $\mathrm{Y} 181 \mathrm{C}$. In the dataset of receiving ART for over60 months, there were 35 mutations that correlated with G190A, 20 mutations for $\mathrm{K} 103 \mathrm{~N}$, and 26 mutations for Y181C. It indicated that with the ART extended, more accessory mutations would emerged.

\section{Discussion}

This research was based on a cohort study including 204 patients taking first-line ART therapy since early stage infection. By the end of 2012, the median treatment duration was 86.4 months (77.6-98.0 months), including 46 patients received ART for over 100 months (22.5\%). In our research, after the ART treatment for over 72 months, 55.5\% patients had their viral load suppressed and $78.6 \%$ patients kept CD4 counts over 200 cells/ml. It seems that the firstline ART could still possibly be effective after long-term treatment.

Though the first-line ART is potent method to fight against HIV, but the development of drug resistance could make ART less effective [24-27]. NNRTI associated drug resistance mutations could compromise the success of NNRTI-containing ART [28-30]. Among these mutations, K103N Y181C and G190A are the most frequent NNRTI associated drug resistance mutations. In a research on nevirapine-experienced individuals, the frequencies of these mutations were $43 \%, 46 \%$ and $26 \%$ respectively [31]. Among the three NNRTI associated mutations, $\mathrm{K} 103 \mathrm{~N}$ is one of the most clinically important NNRTI resistance mutations; it causes 20- to 50-fold resistance to most available NNRTIs [32,33]. In phenotypic experiments, K103N, Y181C and G190A were defined as the mutations that have almost the same replication fitness with wild type. The rank of fitness among mutant viruses was as follows: wild type (WT) $\geq$ Y $181 \mathrm{C} \geq$ $\mathrm{K} 103 \mathrm{~N} \geq \mathrm{G} 190 \mathrm{~A} \geq \mathrm{V} 106 \mathrm{~A} \geq \mathrm{P} 236 \mathrm{~L} \geq \mathrm{G} 190 \mathrm{~S}$ [34,35]. Besides the replication fitness, K103N can persist for a long time in naive patients, over 2 years in a present case report 
Table 5 Correlated mutations in Single Genome Amplification dataset

\begin{tabular}{|c|c|c|c|c|c|}
\hline & Position 1 & $\begin{array}{c}\text { Mutation } \\
\text { type }\end{array}$ & Position2 & Ckaks & Lod \\
\hline \multicolumn{6}{|c|}{ ART for 12 months } \\
\hline & $\mathrm{K} 103 \mathrm{~N}$ & NRTI & D67N & 5 & 2.93 \\
\hline & & & T69D & 8 & Inf \\
\hline & & & K70R & 16 & 9.37 \\
\hline & & NNRTI & Y181C & 26 & 15.23 \\
\hline & & & $\mathrm{H} 221 \mathrm{Y}$ & 17 & 9.96 \\
\hline & Y181C & NRTI & D67N & 5 & 2.93 \\
\hline & & & T69D & 8 & Inf \\
\hline & & & K70R & 1.12 & 5.27 \\
\hline & & NNRTI & K103N & 2 & 29.44 \\
\hline & & & $\mathrm{H} 221 \mathrm{Y}$ & 17 & 9.96 \\
\hline & G190A & NRTI & None & & \\
\hline & & NNRTI & K101E & 29 & 16.98 \\
\hline \multirow{13}{*}{$\begin{array}{l}\text { ART for over } \\
60 \text { months }\end{array}$} & $\mathrm{K} 103 \mathrm{~N}$ & NRTI & T69D & 12 & $\operatorname{lnf}$ \\
\hline & & NNRTI & K219R & 88 & 6.75 \\
\hline & Y181C & NRTI & D67N & 11.5 & 14.12 \\
\hline & & & T69D & 2 & $\operatorname{lnf}$ \\
\hline & & NNRTI & $\mathrm{K} 103 \mathrm{~N}$ & 2.25 & 9.41 \\
\hline & & & $\mathrm{H} 221 \mathrm{Y}$ & 26 & 15.96 \\
\hline & G190A & NRTI & M41L & 21.25 & 88.84 \\
\hline & & & D67N & 7.33 & 13.51 \\
\hline & & & T69D & 12 & $\operatorname{lnf}$ \\
\hline & & NNRTI & K101E & 13.8 & 42.37 \\
\hline & & & K103N & 12 & 11.47 \\
\hline & & & Y181C & 6.67 & 24.56 \\
\hline & & & $\mathrm{H} 221 \mathrm{Y}$ & 3.33 & 12.28 \\
\hline
\end{tabular}

Note: Ckaks indicates the ka/ks ratio of two mutations. Here, it stands for the $\mathrm{ka} / \mathrm{ks}$ ratio for $\mathrm{M} 184 \mathrm{~V}$ and the correlated mutations.

Lod is the confident score for positive selection, If LOD $>2$, the positive selection is significant.

Inf indicates the maximum infinity.

[36]. K103N also can be found in blood mononuclear cell (PBMC) DNA, with no K103N observed in plasma $[37,38]$. All the previous research indicated that K103N can steadily exist in plasma and PBMC, and quasispecies with K103N could be more possibly to survive in the surrounding with NVP.

In our research, the result was different with that in vitro study. We found that during the long-term ART treatment, the frequency of K103N, Y181C and G190A were not kept steady, the fact is the frequency of quasispecies with K103N decreased, and could even vanish in SGA sequences, while the proportion of Y181C and G190A could increase from $0 \%$ to nearly $100 \%$. This result was also identified in a 204-patinets long-term cohort study.
Based on the results, we estimated that among the three strong NNRTI drug resistance mutations, K103N, Y181C and G190A, there may be some competition process in long-term ART. In the initial period of NVPcontaining ART, K103N, Y181C and G190A emerged in different rate among quasispecies which $\mathrm{K} 103 \mathrm{~N}$ and G190A had a higher rate than Y181C [39]. Consider the fact that three mutations have similar replication fitness and the replication fitness which are associated with mutant prevalence in vivo [40-42]. Mutation emerged late would develop to the proper proportion associated with its replication fitness, while the proportion of mutation emerged earlier would reduced because the late emerged mutation took part of its dominant role. Then these three mutations would finally break the imbalanced and unequal proportion which was established in initial ART period.

The result of $\mathrm{cKa} / \mathrm{Ks}$ ratio could provide another support for the competition hypothesis. Among the K103N, Y181C and G190A, they were not always positively correlated with each other, but may turn to negative correlation with the time of receiving ART. It indicated that although in vitro study, the three mutations all had high replication rate and less viral fitness reduction than other NNRTI mutations, variants with these mutations were not so strong in vivo when existed in plasma at same time, they were not always favored by variant under ART pressure. Some competition effect among them may change the frequency of these mutations.

Here is a question according to the research of Jiong Wang [42], the reduced fitness for G190A mutants may not explain the increased frequency of G190A variants over time. It is true that G190A alone can reduce viral fitness, but another research of Jiong Wang [23] found that the variant with K101E + G190S replicated better in the presence of NNRTIs than in the absence of drug, it indicate that mutation K101E may have some effect on the mutant of Codon 190 to enhance the viral fitness. In our study, the frequency of K101E had a similar trend with that of G190A in SGA result, and nearly 30\% (3/9, 4/16, 7/23, 10/27) K101E emerged with G190A in standard genotyping result. This may partly explain the question that the increasing of G190A frequency in long-term ART.

The further mechanism and detail of the competition process were remaining unclear; we may need nextgeneration sequencing and other techniques to go deep in this question. At least we believe this changing of NNRTI mutations is crucial in long-term ART treatment, especially for the country with limited antiviral drugs.

\section{Abbreviations}

HIV: Human immunodeficiency virus; ART: Antiretroviral therapy; NRTI: Nucleoside reverse transcriptase inhibitors; NNRTI: Non-nucleoside reverse transcriptase inhibitors; PCR: Polymerase chain reaction;

TAMs: Thymidine analogue mutations. 


\section{Competing interests}

The authors declare that they have no competing interests.

\section{Authors' contributions}

Conceived and designed the experiments: YCW HX YMS. Performed the experiments: YCW. Analyzed the data: YCW YF. Contributed reagents/ materials/analysis tools: PFM, JL, JJW, YHR, and QBZ. Wrote the manuscript: YCW HX. All authors read and approved the final manuscript.

\section{Acknowledgments}

We thank Prof. Chunfu Yang (International Laboratory Branch USA CDC) for suggestions and comments. We also thank Pengfei Ma, Peng Hong and Cui He who provided technical support for this work. Jenny Hsi provided outstanding administrative support.

\section{Funding}

This work was supported by grants from the Ministry of Science and Technology of China (2008ZX10001-004), Chinese State Key Laboratory for Infectious Disease Develop Grant (2011SKLID102) and Ministry of Science and Technology of China (2012ZX10001-002). This study was also supported by grants from the Guangxi Honor Scholar.

\section{Author details}

${ }^{1}$ Beijing Center for Diseases Prevention and Control, Beijing, China. ${ }^{2}$ State Key Laboratory for Infectious Disease Prevention and Control, National Center for AIDS/STD Control and Prevention, Chinese Center for Disease Control and Prevention, Collaborative Innovation Center for Diagnosis and Treatment of Infectious Diseases, Beijing, China. ${ }^{3}$ Henan Center for Disease Control and Prevention, Zhengzhou, China. ${ }^{4}$ Anhui Center for Disease Control and Prevention, Hefei, China.

Received: 25 November 2013 Accepted: 27 October 2014 Published: 21 November 2014

\section{References}

1. Zhang FJ, Pan J, Yu L, Wen Y, Zhao Y: Current progress of China's free ART program. Cell Res 2005, 15(11-12):877-882.

2. National Center for AIDS/STD Control and Prevention, China CDC: 2011 Estimates for the HIV/AIDS Epidemic in China. Chin J AIDS STD 2012, 18(1):1-5.

3. Zhang FJ: National Free HIV Antiretroviral Treatment Handbook. People's Medical Publishing House 2008, 25-26.

4. World Health Organization: Antiretroviral therapy for HIV infection in adults and adolescents: recommendations for a public health approach. Geneva, Switzerland: WHO, HIV Department; 2006. Available at: http://www.who.int/ hiv/pub/guidelines/artadultguidelines.pdf. Accessed 12 December 2007.

5. Taylor S, Boffito M, Khoo S, Smit E, Back D: Stopping antiretroviral therapy. AIDS 2007, 21:1673-1682

6. Panel on Antiretroviral Guidelines for Adults and Adolescents: Guidelines for the use of antiretroviral agents in HIV-1-infected adults and adolescents. Department of Health and Human Services; 2012. Available at http://www. Siripassorn. AIDS Research and Therapy 2013, 10:4 Page 8 of 9: Accessed [December 5, 2011].

7. van Griensven J, Zachariah R, Rasschaert F, Mugabo J, Atte EF, Reid T: Stavudine- and nevirapine-related drug toxicity while on generic fixeddose antiretroviral treatment: incidence, timing and risk factors in a three-year cohort in kigali, rwanda. Trans R Soc Trop Med Hyg 2010, 104:148-153.

8. Manosuthi W, Sungkanuparph $S$, Tansuphaswadikul $S$, Inthong $Y$, Prasithsirikul W, Chottanapund S, Mankatitham W, Chimsuntorn S, Sittibusaya C, Moolasart V, Chumpathat N, Termvises P, Chaovavanich A: Incidence and risk factors of nevirapineassociated skin rashes among HIV-infected patients with CD4 cell counts $<250$ cells/microL. Int J STD AIDS 2007, 18:782-786

9. Antinori A, Baldini F, Girardi E, Cingolani A, Zaccarelli M, Di Giambenedetto S, Barracchini A, De Longis P, Murri R, Tozzi V, Ammassari A, Rizzo MG, Ippolito G, De Luca A: Female sex and the use of anti-allergic agents increase the risk of developing cutaneous rash associated with nevirapine therapy. AIDS 2001, 15:1579-1581.
10. Johnson VA, Brun-Vezinet F, Clotet B, Gunthard HF, Kuritzkes DR, Pillay D, Schapiro JM, Richman DD: Update of the drug resistance mutations in HIV-1: December 2009. Top HIV Med 2009, 17:138-145.

11. Antinori A, Zaccarelli M, Cingolani A, Forbici F, Rizzo MG, Trotta MP, Di Giambenedetto S, Narciso P, Ammassari A, Girardi E, De Luca A, Perno CF: Cross-resistance among nonnucleoside reverse transcriptase inhibitors limits recycling efavirenz after nevirapine failure. AIDS Res Hum Retroviruses 2002, 18:835-838.

12. Sinha S, Shekhar RC, Ahmad H: Prevalence of HIV drug resistance mutation in the northern Indian population after failure of the first line antiretroviral therapy. Curr HIV Res 2012, 10(6):532-538.

13. Manasa J, Katzenstein D, Cassol S, Newell ML, de Oliveira T: Primary drug resistance in South Africa: data from 10 years of surveys. AIDS Res Hum Retroviruses 2012, 28(6):558-565. doi:10.1089/AID.2011.0284. Epub 2012 Mar 12.

14. Lehman DA, Wamalwa DC, McCoy CO, Matsen FA, Langat A, Chohan BH, Benki-Nugent S, Custers-Allen R, Bushman FD, John-Stewart GC, Overbaugh J: Low-frequency nevirapine resistance at multiple sites may predict treatment failure in infants on nevirapine-based treatment. J Acquir Immune Defic Syndr 2012, 60(3):225-233. doi:10.1097/QAl.0b013e3182515730.

15. Jiong W, Bambara RA, Demeter LM, Dykes C: Reduced Fitness in Cell Culture of HIV-1 with Nonnucleoside ReverseTranscriptase InhibitorResistant Mutations Correlates with RelativeLevels of ReverseTranscriptase Content andRNase H Activity in Virions. J Virol 2010, 84(18):9377-9389.

16. Xu HT, Oliveira M, Quan Y, Bar-Magen T, Wainberg MA: Differential impact of the HIV-1 non-nucleoside reverse transcriptase inhibitor mutations K103Nand M230L on viral replication and enzyme function. J Antimicrob Chemother 2010, 65(11):2291-2299. Epub 2010 Sep 18.

17. Bannister WP, Ruiz L, Cozzi-Lepri A, Mocroft A, Kirk O, Staszewski S, Loveday C, Karlsson A, Monforte A, Clotet B, Lundgren JD, EuroSIDA study group: Comparison of genotypic resistance profiles and virological response between patients starting nevirapine and efavirenz in EuroSIDA. AIDS 2008, 22(3):367-376.

18. Ceccherini-Silberstein F, Svicher V, Sing T, Artese A, Santoro MM, Forbici F, Bertoli A, Alcaro S, Palamara G, d'Arminio Monforte A, Balzarini J, Antinori A, Lengauer T, Perno CF: Characterization and structural analysis of novel mutations in human immunodeficiency virus type 1 reverse transcriptase involved in the regulation of resistance to nonnucleoside inhibitors. J Virol 2007, 81(20):11507-11519.

19. Salazar-Gonzalez JF, Bailes E, Pham KT, Salazar MG, Guffey MB, Keele BF, Derdeyn CA, Farmer P, Hunter E, Allen S, Manigart O, Mulenga J, Anderson JA, Swanstrom R, Haynes BF, Athreya GS, Korber BT, Sharp PM, Shaw GM, Hahn BH: Deciphering Human Immunodeficiency Virus Type 1 Transmission andEarly Envelope Diversification by Single-Genome Amplificationand Sequencing. J Virol 2008, 82(8):3952-3970.

20. Butler DM, Pacold ME, Jordan PS, Richman DD, Smith DM: The efficiency of single genome amplification and sequencing is improved by quantitation and use of a bioinformatics tool. J Virol Methods 2009, 162(1-2):280-283.

21. Hurst LD: The Ka/Ks ratio: diagnosing the form of sequence evolution. Trends Genet 2002, 18:486.

22. Chen L, Perlina A, Lee CJ: Positive selection detection in 40,000 Human Immunodeficiency Virus (HIV) type 1 sequences automatically identifies drug resistance and positive fitness mutations in HIV protease and reverse transcriptase. J Virol 2004, 2004:3722-3732.

23. Wang J, Li D, Bambara RA, Dykes C: Reverse transcriptase backbone can alter the polymerization and RNase activities of non-nucleoside reverse transcriptase mutants K101E + G190S. J Gen Viro/ 2013, 94(Pt 10):2297-2308.

24. Zhang F, Haberer JE, Wang Y, Zhao Y, Ma Y, Zhao D, Yu L, Goosby EP: The Chinese free antiretroviral treatment program: challenges and responses. AIDS 2007, 21(Suppl 8):S143-S148.

25. DeGruttola V, Dix L, D’Aquila R, Holder D, Phillips A, Ait-Khaled M, Baxter J, Clevenbergh P, Hammer S, Harrigan R, Katzenstein D, Lanier R, Miller M, Para M, Yerly S, Zolopa A, Murray J, Patick A, Miller V, Castillo S, Pedneault L, Mellors J: The relation between baseline HIV drug resistance and response to antiretroviral therapy: re-analysis of retrospective and prospective studies using a standardized data analysis plan. Antivir Ther 2000, 5:41-48.

26. D'Aquila RT, Johnson VA, Welles SL, Japour AJ, Kuritzkes DR, DeGruttola V, Reichelderfer PS, Coombs RW, Crumpacker CS, Kahn JO, Richman DD: Zidovudine resistance and HIV-1 disease progression during antiretroviral therapy. AIDS Clinical Trials Group Protocol 116B/117 Team and the Virology Committee Resistance Working Group. Ann Intern Med 1995, 122:401-408. 
27. Zolopa AR, Shafer RW, Warford A, Montoya JG, Hsu P, Katzenstein D, Merigan TC, Efron B: HIV-1genotypic resistance patterns predict response to saquinavir-ritonavir therapy in patients in whom previous protease inhibitor therapy had failed. Ann Intern Med 1999, 131:813-821.

28. Jourdain G, Ngo-Giang-Huong N, Le Coeur S, Bowonwatanuwong C, Kantipong P, Leechanachai P, Ariyadej S, Leenasirimakul P, Hammer S, Lallemant M, Perinatal HIV Prevention Trial Group: Intrapartum exposure to nevirapine and subsequent maternal responses to nevirapine-based antiretroviral therapy. N Engl J Med 2004, 351:229-240.

29. Lockman S, Shapiro RL, Smeaton LM, Wester C, Thior I, Stevens L, Chand F, Makhema J, Moffat C, Asmelash A, Ndase P, Arimi P, van Widenfelt E, Mazhani L, Novitsky V, Lagakos S, Essex M: Response to antiretroviral therapy after a single, peripartum dose of nevirapine. N Engl J Med 2007, 356:135-147.

30. Stringer JSA, McConnell MS, Kiarie J, Bolu O, Anekthananon T, Jariyasethpong T, Potter D, Mutsotso W, Borkowf CB, Mbori-Ngacha D, Muiruri P, Ong'ech JO, Zulu I, Njobvu L, Jetsawang B, Pathak S, Bulterys M, Shaffer N, Weidle PJ: Effectiveness of non-nucleoside reverse-transcriptase inhibitor-based antiretroviral therapy in women previously exposed to a single intrapartum dose ofnevirapine: a multi-countrym, Prospective Cohort Study. PLoS Med 2010, 7:e1000233.

31. Reuman EC, Rhee SY, Holmes SP, Shafer RW: Constrained patterns of covariation and clustering of HIV-1 non-nucleoside reverse transcriptase inhibitor resistance mutations. J Antimicrob Chemother 2010, 65(7):1477-1485.

32. Casado JL, Hertogs K, Ruiz L, Dronda F, Van Cauwenberge A, Arnó A, Garcia-Arata I, Bloor S, Bonjoch A, Blazquez J, Clotet B, Larder B: Non-nucleoside reverse transcriptase inhibitor resistance among patients failing a nevirapine plus protease inhibitor-containing regimen. AIDS 2000, 14:F1-F7.

33. Joly V, Moroni M, Concia E, Lazzarin A, Hirschel B, Jost J, Chiodo F, Bentwich Z, Love WC, Hawkins DA, Wilkins EG, Gatell AJ, Vetter N, Greenwald C, Freimuth WW, de Cian W: Delavirdine in combination with zidovudine in treatment of human immunodeficiency virus type 1-infected patients: evaluation of efficacy and emergence of viral resistance in a randomized, comparative phase III trial. Antimicrob Agents Chemother 2000, 44:3155-3157.

34. Wang J, Bambara RA, Demeter LM, Dykes C: Reduced fitness in cell culture of HIV-1 with nonnucleoside reverse transcriptase inhibitor-resistant mutations correlates with relative levels of reverse transcriptase content and RNase $\mathrm{H}$ activity in Virions[J]. J Virol 2010, 9:9377-9389.

35. Xu HT, Oliveira M, Quan YJ, Bar-Magen T, Wainberg MA: Differential impact of the HIV-1 non-nucleoside reverse transcriptase inhibitor mutations $\mathrm{K} 103 \mathrm{Nand} \mathrm{M} 230 \mathrm{~L}$ on viral replication and enzyme function[J]. Antimicrob Chemother 2010, 65(11):2291-2299.

36. Zaccarelli M, Marconi P, Visco-Comandini U, Liuzzi G, Sette P, Acinapura R, Mosti S, Ammassari A, Perno CF, Antinori A: Evidence of dual sexual transmission of multi-resistant HIV with two years persistence of resistance to NRTI and NNRTI: a case report. Infection 2008, 36(2):178-180.

37. Saladini F, Vicenti I, Razzolini F, Zazzi M: Detection of residual human immunodeficiency virus type 1 reverse transcriptase K103N minority species in plasma RNA and peripheral blood mononuclear cell DNA following discontinuation of non-nucleoside therapy. Clin Microbiol Infect 2010, 16(7):848-851.

38. Loubser S, Balfe P, Sherman G, Hammer S, Kuhn L, Morris L: Decay of K103N mutants in cellular DNA and plasma RNA after single-dose nevirapine to reduce mother-to-child HIV transmission. AIDS 2006, 20(7):995-1002.

39. Boltz VF, Zheng Y, Lockmanc S, Hong F, Halvas EK, Mclntyre J, Currier JS, Chibowa MC, Kanyama C, Nair A, Owino-Ong'or W, Hughes M, Coffin JM, Mellors JW: Role of low-frequency HIV-1 variants in failure of nevirapinecontaining antiviral therapy in women previously exposed to singledose nevirapine. Proc Natl Acad Sci U S A 2011, 108(22):9202-9207.

40. Archer RH, Dykes C, Gerondelis P, Lloyd A, Fay P, Reichman RC, Bambara RA, Demeter LM: Mutants of human immunodeficiency virus type 1 (HIV-1) reverse transcriptase resistant to nonnucleoside reverse transcriptase inhibitors demonstrate altered rates of RNase $\mathrm{H}$ cleavage that correlate with HIV-1 replication fitness in cell culture. J Virol 2000, 74:8390-8401.
41. Gerondelis P, Archer RH, Palaniappan C, Reichman RC, Fay PJ, Bambara RA, Demeter LM: The P236L delavirdine-resistant human immunodeficiency virus type 1 mutant is replication defective and demonstrates alterations in both RNA 5'-end- and DNA 3'-end-directed RNase $\mathrm{H}$ activities. J Virol 1999, 73:5803-5813.

42. Wang J, Dykes C, Domaoal RA, Koval CE, Bambara RA, Demeter LM: The HIV-1 reverse transcriptase mutants G190S and G190A, which confer resistance to non-nucleoside reverse transcriptase inhibitors, demonstrate reductions in RNase $\mathrm{H}$ activity and DNA synthesis from tRNA $($ Lys, 3) that correlate with reductions in replication efficiency. Virology 2006, 348:462-474.

doi:10.1186/1742-6405-11-36

Cite this article as: Wang et al:: The development of drug resistance mutations K103N Y181C and G190A in long term Nevirapine-containing antiviral therapy. AIDS Research and Therapy 2014 11:36.

\section{Submit your next manuscript to BioMed Central and take full advantage of:}

- Convenient online submission

- Thorough peer review

- No space constraints or color figure charges

- Immediate publication on acceptance

- Inclusion in PubMed, CAS, Scopus and Google Scholar

- Research which is freely available for redistribution

Submit your manuscript at www.biomedcentral.com/submit
C Biomed Central 